\title{
NATO and the environment: the committee on the challenges of modern society
}

Article

Accepted Version

Risso, L. (2016) NATO and the environment: the committee on the challenges of modern society. Contemporary European History, 25 (3). pp. 505-535. ISSN 1469-2171 doi: https://doi.org/10.1017/S0960777316000187 Available at https://centaur.reading.ac.uk/55429/

It is advisable to refer to the publisher's version if you intend to cite from the work. See Guidance on citing.

Published version at: http://journals.cambridge.org/action/displayJournal?jid=CEH

To link to this article DOI: http://dx.doi.org/10.1017/S0960777316000187

Publisher: Cambridge University Press

All outputs in CentAUR are protected by Intellectual Property Rights law, including copyright law. Copyright and IPR is retained by the creators or other copyright holders. Terms and conditions for use of this material are defined in the End User Agreement.

\section{www.reading.ac.uk/centaur}

\section{CentAUR}

Central Archive at the University of Reading

Reading's research outputs online 
NATO and the Environment:

The Committee on the Challenges of Modern Society

\author{
Preview
}

Not for citation

To appear in Contemporary European History

Volume 26 issue 1

2017

\title{
Abstract
}

Launched with considerable fanfare in 1969, the Committee on the Challenges of Modern Society (CCMS) was supposed to bring new life to NATO by both re-energising public support and engaging with a variety of themes, issues and partners well beyond the alliance's traditional scope. The first aim of this article is to go beyond the careful media operation that surrounded the launch of the CCMS and to examine the scepticism and resistance of some European partners, particularly the British. The second aim is to demonstrate that NATO started to think in terms of crisis management, disaster relief and environmental disasters well before 1989. The sheer military strength of the alliance and of its partners did remain central - and notably came back to the forefront in 1979 - but the alliance did start to see itself as a geopolitical player and to consider engagement beyond its strictly defined geographical area as early as 1969 . 
Science and technology have always played (?) an important role in NATO's strategic concept and defence planning. During the Cold War, it was essential to keep the edge in scientific and technological research and to make sure that the West could compete with the Soviet Bloc. At the same time, cooperation in scientific and technological development was an important factor for the cohesion of the alliance itself. Since the 1960s, many member governments became concerned about the increasing gap between the scientific and technological achievements of the United States and of Western Europeans, who lagged behind. The problem became more serious in the 1970s, when the balance of payments between the two sides of the Atlantic was affected by patent costs. ${ }^{1}$ This was also the time when student and worker movements brought about a new wave of protests against the establishment, the older generation of politicians and the logic of the Cold War as a whole. The political discourse saw the emerging of new ideas, including the beginning of a new environmental awareness. The peace and environmental movements gained considerable momentum and became important political actors. Contrary to the previous decade, the peace movements were separated from international communism, and in fact they were quite critical of the communist regimes as much as the Western governments for their lack of commitment to peace and international dialogue and for the economic, political and environmental consequences of the proliferation of nuclear weapons. ${ }^{2}$ The new political and environmental consciousness directly affected NATO, which was seen as responsible for perpetrating the logic of the Cold War and for being unaware of the concerns faced by its younger generations. Support for the alliance was dwindling fast.

Gone were the days of a clear vision of the world in black and white in which NATO had simply to point to the number of Soviet divisions stationed in Eastern Europe to demonstrate the need for the alliance and for the rearmament of the West. From the late 1960s on, levels of trust in Soviet goodwill were declining and there were virtually no pockets in Western society where the Soviet Union was genuinely seen as an alternative model of society. If NATO wanted to win the hearts and minds of the new generations, it had to shift its focus away from creating a negative image of the Soviet Union, as this had become redundant. At a time of détente and diplomatic dialogue with the East, it was important to demonstrate that the alliance had to continue to be militarily strong and politically cohesive so to be able to stand in a strong negotiating position against the Soviet Union. At the same time, it was equally important to show engagement with youth concerns and particularly with environmental issues. ${ }^{3}$

This article has two key aims. First of all, it traces the history of the Committee on the Challenges of Modern Society (CCMS). As a key component of NATO's political and scientific dimensions, the CCMS was central to the alliance's attempt to engage with the environmental challenges of its time. Launched with considerable fanfare in 1969, the CCMS was supposed to bring new life to NATO both in terms of re-energising public support as well as engaging with a variety of themes, issues and partners well beyond its traditional scope. As this article will discuss, NATO started to think in terms of crisis management, disaster relief and environmental disasters well before 1989. The sheer military strength of the alliance and of its partners did remain central - and notably returned to the forefront in 1979 - but the alliance did start to see itself as a geopolitical player, outward-looking and able to start new dialogue with the East on new ground as early as 1969 . 
The second aim of this article is to go beyond the careful media operation that surrounded the launch of the CCMS and to look at the degree of scepticism and resistance put forward by some European partners. The CCMS was President Nixon's pet project. The American President saw it as a tool to boost support for NATO at home and to reach a higher level of political cohesion within the alliance itself. He assigned high calibre names like Daniel Patrick Moynihan and Henry Kissinger to follow the project and to convince the allies to support it. Yet, both the content of the idea and the way in which it was promoted irritated several allies and caused scepticism and lack of enthusiasm. NATO's official publications, press communiqués and final resolutions suggest that there was great support for Nixon's proposal. Documents from the British National Archives, however, help demonstrate the British attempts to moderate US enthusiasm and to carry out a careful balancing act between showing themselves willing to support the Americans while at the same time trying to gain time in the hope that the project would collapse on its own weaknesses. Thus, this article contributes to the argument that the history of NATO is the history of a continuous - and often tortuous - negotiations between its members. Even when, like in this case, the United States threw all its political weight and high-calibre names to support the project, it had to face resistance and settle for less than it had hoped.

\section{The Beginning of NATO's Third Dimension: The Science Committee}

The Science Committee was launched with the aim of strengthening NATO's 'third (i.e. scientific and technological) dimension', thus complementing the alliance's military and political roles. Its key goal was to foster scientific education, cooperation and research. NATO science had its roots in article 2 of the Washington Treaty, which defined the alliance as a political organisation whose aim was to encourage political and economic cooperation among its members. ${ }^{4}$ NATO's third dimension was not invented in the 1969. It was an integral part of the alliance's strategy and security concept since its inception. The first joint scientific projects were - not surprisingly - closely linked to military defence and weapon standardisation. However, it soon became clear that if the alliance wanted all its members to make substantial progress in the field of scientific research, it had to promote a wide range of initiatives and joint projects. ${ }^{5}$

The launching of the Sputniks in October and November 1957 caused consternation in the West. They were a tangible sign of the quick pace with which the Soviet Union was closing the gap in terms of research and technological development. NATO officials later spoke of a true 'psychological shock' and it/the launch(?) gave further impetus to talks already taking place following the recommendations of the Three Wise Men Report. ${ }^{6}$ The Atlantic Council quickly approved the creation of the Science Committee (SCOM), which met for the first time in March 1958 under the chairmanship of the new NATO's Science Adviser. ${ }^{7}$

The aim of the Science Committee was to advise the Council on issues connected to scientific and technological development and ways in which member countries could strengthen scientific cooperation and - most importantly - education, so as to be able to increase the number of Western scientists and engineers. The very fact that only a few years later the post of Science Adviser was raised to Assistant Secretary General for Scientific Affairs (1962) is a sign of the increased importance of science within NATO. 
Initially, the Science Committee made recommendations for the strengthening of pure science. The ultimate aim was to increase the number of scientists and technicians across the alliance and to improve scientific and technical education. The programme aimed at reinforcing international cooperation including the free flow of specialists as well as of knowledge between the member states. Many of its early project had pragmatic aims: in 1959, for example, the Science Committee established the Subcommittee on Oceanographic Research, the Advisory Panel on the Advanced Study Institutes Program and the Advisory Panel on Meteorology. In 1960, it created Advisory Panels on the Research Grants Program, on Defence Psychology (later to become the Advisory Panel on Human Factors) and on Operational Research, and in 1961 the Advisory Panel on Radio-meteorology. ${ }^{8}$

It is important not to overestimate the impact that these initiatives had on the national research cultures and agendas. The Assistant Secretary General for Scientific Affairs had no actual power to influence the research carried out by the member states and could not shape their priorities, let alone the institutional cultures of their universities and research centres. As John Krige has pointed out, joint research ventures were often aborted because of the fear of sharing cutting-edge discoveries with other members or the risk that information relating to national security may be leaked. As a result, it was common for the national delegations on the Civil Budget Committee to veto the most audacious projects. Thus, after a promising start, the pure science program budget stabilised and the projects approved settled at low and rather unadventurous levels, where all national delegations felt comfortable. These projects were hardly ground-breaking and exciting for scientists and therefore did not receive the participation of the biggest names in the field as it was initially hoped. ${ }^{9}$

It is also worth pointing out that the decision-making process and research priorities of the Science Committee were determined by the experts volunteered by the national governments. As such, the experts were conscious of their own government's concerns and the interests of the Committee were routinely subordinated to those of its individual members. In addition, officers responsible for everyday science-related issues within the national delegations often had little or no scientific training. This is because in most cases NATO science was hardly perceived as a priority by the national governments. Consequently, the person assigned to 'science matters' was more often than not one of the most junior members of the delegation and it was not uncommon for many of them to have little or no scientific training. Thus, while nominally all nations were interested in promoting closer scientific cooperation, in practice most of them did little more than pay lip service.

The United States was the most enthusiastic participant and as such it bore a large share of the costs for several research projects. Not surprisingly, in the light of its commitments, the United States demanded a say in the Committee's priorities and successfully had an American appointed Assistant Secretary General for the first ten years. In fact, it soon became a tradition that the Science Adviser, and later Assistant Secretary Generals for Scientific Affairs, was an American academic. For the first ten years all ASG for Scientific Affairs were physicists based in American universities: Norman Ramsey (Harvard), Frederic Seitz (Illinois), William A. Nierenberg (Berkeley), William Allis (MIT). The last American ASG for Scientific Affairs was John McLucas (1964-1966), who came from the Department of Defence. 
American calls for tighter collaboration and higher investment were hindered by the opposition of the other delegations, who wanted to have an equal say on the matter. The result was frustration and lack of enthusiasm for pure science across the spectrum. ${ }^{10}$ Military leaders were hardly enthused by scientific cooperation in pure science and tended to favour its technical implementations for defence purposes only. Attempts to improve scientific cooperation were thus doomed to failure. ${ }^{11}$

National research institutes initially seemed interested. They offered administrative services and, wherever possible, financial support to the pure science programme in the hope that this would help them attract further funding from their own national governments. ${ }^{12}$ Further support came from the North Atlantic Assembly, who discussed the issue at length during their annual meetings. Yet, all this had little effect on national policies. National governments continued to be reluctant to contribute money to projects that they deemed unrealistic and far-fetched. They were interested in the Science Committee only as a way to channel additional funds for their own national research institutes; however, when this appeared not to be the case, the lack of interest jeopardised the Committee's action. Academics and researchers were also often opposed to the project as they feared that new international research institutes would drain away the best minds. The high level of centralisation and bureaucratisation also condemned the Science Committee to move slowly and to settle for the lowest common denominator to which all countries could agree. ${ }^{13}$

\section{The Launch of the Committee on the Challenges of Modern Society}

In the late 1960s air and water pollution were widely discussed by experts, government agencies and the public more broadly. The rapid pace of industrialisation and dramatic economic changes meant that all NATO countries suffered industrial waste problems, water and air pollution, congestion of the transportation systems and overcrowding of their major towns. Wide sectors of the public, and particularly the younger generations, became increasingly critical of the way in which the economy was run and the environment was damaged. ${ }^{14}$

This was of course also the moment when President de Gaulle became increasingly critical of the American leadership and eventually withdrew France from the integrated allied command, demanding the immediate relocation of NATO Headquarters away from French soil and the closure of all the alliance's military bases in France. At the heart of the Gaullist decision was the questioning of NATO's political legitimacy, the nature of transatlantic relations and the role of Western Europe in the Cold War. $^{15}$

NATO's answer to this very heterogeneous set of challenges was to stress the provisions of article 2, which provided for closer economic, political and cultural cooperation among its members. The Harmel Report of 1967 argued that the post-Stalin era NATO was necessary precisely because it meant more than military defence. The report made clear that a balance of military power was a prerequisite for the creation of the climate of stability in the East-West relations and that it was an essential precondition to allow the West to achieve progress in international negotiations with the Soviet bloc on issues like the division of Germany and the position of Berlin. At the same time, among the recommendations put forward by the report was the need to enhance political and scientific cooperation to boost popular support for the alliance in the member countries. The Harmel Report advocated strong 
defence along with new diplomatic relations with the Eastern Bloc and called on NATO members to use the alliance in the interests of détente. ${ }^{16}$

As far as NATO's information activities were concerned, the Harmel Report stated that public support for the alliance's defence efforts was vital to the accomplishment of the tasks ahead, and that it was crucial to explain to the public both the rationale underlying NATO's strategy and the alliance's efforts to preserve the military and defence balance between East and West. Public support for the defence effort was an essential for the credibility of NATO's deterrent strategy. Without it, the deterrent value of NATO would be seriously undermined, as military and nuclear capabilities would mean little if there was not public support for their use. The approval of the Report therefore brought a review of the NATO information effort, demonstrating that it had to focus more clearly on fostering support among the wider public and on explaining the need for military strength as well as political cohesion at a time when neither seem to have been achieved at a satisfactory degree.

This is when the United States proposed that the alliance establish a new body to 'explore ways in which the experiences and resources of the Western nations could most effectively be marshalled toward improving the quality of life of our people'. ${ }^{17}$ Nixon made the announcement at the North Atlantic Council meeting in Washington, coinciding with the twentieth anniversary of the foundation of NATO. He declared his personal interest in the matter and pushed for immediate action. Almost immediately, high-profile contacts took place in the capital's embassies. It was clear that the Nixon Administration was very keen on the project, as well as well organised and ready to push hard for immediate implementation. Yet, as discussed later, the 'steamroller approach' caused substantial irritation and frustration in the European capitals.

In the eyes of the Americans, the new Committee would demonstrate the multi-faceted nature of the alliance, its peaceful nature and its ability to adapt to new challenges. ${ }^{18}$ Stephen Macekura has argued convincingly that, in effect, Nixon's primary objective was to gain more support for the alliance back at home, where NATO suffered waning support. Other historians, like Brooks Flippen and Jacob Darwin Hamblin, have underlined that Nixon's environmental concerns should be seen primarily as a tool for détente. ${ }^{19}$

Despite the scepticism of several European members - which shall be discussed more in detail later - the North Atlantic Council agreed to establish the Committee on the Challenges of Modern Society (CCMS). ${ }^{20}$ Together with the Science Committee, the CCMS was supposed to become a central part of NATO's 'third dimension', complementing the alliance's military and political roles. The CCMS was much more outward-looking than the Science Committee both in terms of the themes it focused on, like pollution, car safety and urbanisation, which were great concerns of the public, as well as in terms of the level of media attention that it attracted - attention that was encouraged and at times carefully orchestrated by NATO's information officers. $^{21}$

Like the Science Committee, the CCMS too was rooted in article 2, according to which member countries are committed to promote conditions of stability and well-being for their people, and, as such, it was presented as an integral part of the alliance's security concept. According to the new narrative, it had become clear that in addition to protecting the West from military attacks, the alliance had to ensure that national governments were ready to react promptly to natural disasters and that they understood the 
wide-ranging implications of massive industrialisation and urbanisation. Most importantly, it was crucial to prevent natural disasters by working together and by studying the causes and consequences of environmental problems. $^{22}$

From the start, it was understood that the CCMS would be a new kind of committee, revolutionary in mission and modus operandi. The CCMS was to further the political aims and overall cohesion of the alliance by focusing on a limited number of well-defined problems. Learning a lesson from the failures of the Science Committee, the CCMS had a limited mandate, no budget and no fulltime international staff. During the Cold War, the Committee's activity was characterised by a high degree of decentralisation. National representatives, at cabinet and subcabinet levels, met twice a year in plenary sessions. No funds from the NATO budget were allocated and projects had to be initiated by member countries. If the Council approved them, they were administered and paid for by the proposing country and other interested national governments. The 'pilot country' would also coordinate the project's execution, prepare the necessary reports and, most importantly, promote follow-up action at national and international levels. Precisely because of its limited mandate and light structure, it was hoped that the CCMS could avoid the problems that had hampered progress within the Science Committee.

Three key concepts characterised the work of the CCMS: first, all its work should lead to government policy formulation and legislation. Hence, the country who ran the pilot study would also monitor progress and press for follow up action - like, for example, new legislation or further study by exerting political pressure in all international organisations and through bi-lateral contacts. Second, the CCMS would not be running its own independent research but would build upon research carried out by national governments, their research institutions and other international organisations. It would be directed towards questions of government policy formulation and legislation, suggesting ways to bring about improvements to the environment and social policies. ${ }^{23}$ Finally, all CCMS results should be open and accessible to international organisations or individual countries anywhere in the world without prejudice. ${ }^{24}$ Because of the transnational nature of the topics included in the CCMS's scope, the results transcended political ideology and therefore needed to be open to all countries including developing countries and the Communist ones'. ${ }^{25}$ Publicity was deemed crucial as the CCMS dealt with problems that affected the daily life of the citizens of the alliance and beyond and contributed to the policymaking process. NATO had to explain why the alliance was engaging in these new fields and to what extent it was not duplicating what was already being done by other organisations, particularly the Organisation for Economic Cooperation and Development (OECD). ${ }^{26}$

Given that the primary task of the CCMS was to demonstrate the progressive character of the alliance, it was essential to avoid overstatements and minimise disappointment. The risk was that the alliance would become hostage to its own ambitious goals. This was a point put forward mostly by the European members, who were aware of their own public's scepticism regarding anything that may taste, even remotely, like 'propaganda'. Any publicity campaign involving the CCMS had to be carefully measured against the prospects of concrete results and stress that factual results could be obtained only gradually and with the cooperation of all nations involved. All public statements about the CCMS had to avoid overambitious statements, which were deemed counterproductive. ${ }^{27}$ 
All pilot studies were unclassified and were made available to any other countries and international organisations. The press was invited to the CCMS inaugural session and for the first time the invitation was formally extended to journalists from outside the NATO area. Journalists were welcomed at the headquarters and the invitation was renewed every time the CCMS met in plenary session. The CCMS press conferences were very popular with the media and the facilities for the press in the Council Room soon became inadequate and a larger conference room had to be created. ${ }^{28}$

In all NATO and NATO-related publications, the CCMS was given several pages, with pictures and articles by leading experts on the topics studied by the CCMS. The NATO Information Service also commissioned a short film entitled The Committee on the Challenges of Modern Society (1974), which stands out from the rest of the films circulated in this period for its artistic choice of frame and for its lyric tone. ${ }^{29}$ The United States Information Agency also planned a series of film and newsreels to publicise the activity of the CCMS. ${ }^{30}$ Archival documents reveal that the NATO information officers engaged proactively with the national media to give maximum coverage to the first pilot studies carried out by the CCMS. ${ }^{31}$ In all cases, the CCMS was presented to the public as one of the many examples of the multi-faceted nature of the alliance and of its entirely peaceful aims, a refrain repeated several times in all information material items.

The difference with the Science Committee was therefore not only procedural but also substantive: the CCMS was key to the alliance's attempt to engage with the public and to respond to youth's disaffection and concerns. At the same time, the launch of the CCMS marked a decisive step towards a new strategic concept: the label 'environment' encompassed a variety of subjects including disaster relief and crisis management. As discussed later in this article, at the time the CCMS could do little more than recommend more coordination among its members and suggest ways to work together with non-NATO members. It is therefore very difficult to qualify its success. However, the work of the CCMS should be seen as an attempt to redefine the security concept of the alliance and the idea of what constituted a threat. It was a first tangible sign that the alliance was moving towards a different kind of defence, which was not only military defence but defence of their populations and their well being. It points to a new awareness of the importance of out-of-area events and of the need to secure cooperation beyond the alliance itself. These ideas were very new at the time, marking a first important step away from direct military confrontation and helping to lay the basis for the post-1989 NATO's strategy and security.

\section{Behind the Scenes}

According to the NATO Letter and several NATO-related publications, Nixon's proposal for the Committee on the Challenges of Modern Society was ground-breaking. According to the narrative established at the time, the proposal was warmly received by the alliance and its members. The very fact that only eight months after the announcement, the CCMS was already operative was seen as a sign of its significance and widespread support. Subsequent articles in NATO-sponsored publications built on this idea by stressing the significance of the first pilot-studies, magnifying, if not overstating, their impact.

It is therefore important to look at the reasons behind Nixon's 1969 proposal, in addition to his 
personal interest in the environment. ${ }^{32} \mathrm{~A}$ few months after the publication of the Harmel Report, the Czechoslovak crisis shook the alliance; however, it did not alter NATO's basic view that the danger of an all-out Soviet assault was low. The alliance - and particularly its European members - were abuzz about the crisis' implications on détente and were keen to consult about how best to produce a united front. As discussed by several scholars, the history of the alliance during the Cold War was characterised by a tendency to fragmentation whenever tensions in East-West relations subsided. Each time the Soviet threat was allegedly reduced to manageable proportions, the differences among the allies mushroomed into sources of potential division. As a consequence, there were new calls for expanded consultation and pragmatic cooperation particularly from the smaller members. Yet, different views and security strategies persisted and created political tension. The result was 'a growing paradox, in which the alliance actually works better while dissatisfaction about it increases' ${ }^{33}$

The Nixon administration was aware that the alliance's political fragmentation might undermine its deterrent value and was keen to make constructive use of the call for enhanced consultation and increased cooperation. The correspondence between the State Department and the US Delegation at NATO reveals that the Americans were looking for effective ways to cement the alliance and overcome the difficulties of too many 'special cases'. ${ }^{34}$ In addition, at a time when the United States was pursuing bilateral relations with Moscow, it was important to show that Washington remained committed to the alliance both for the success of the negotiations themselves as well as to reassure the NATO allies. In the eyes of the American administration, the launch of the CCMS squared the circle. It offered the opportunity to show their commitment to the alliance, to address the concern of the younger generations and to bring new non-ideological issues to the diplomatic table. Hence the CCMS was crucial to reassure the European allies and, as Macekura has argued, to boost support for the alliance at home. ${ }^{35}$ Jacob Darwin Hamblin argues that Nixon saw the CCMS primarily - if not exclusively - as a tool with which to engage on environmental issues with the East as this allowed the President to move the discussion on to non-ideological territory. Yet, recent published sources suggest that appeasing the NATO allies while the United States was engaged in bi-lateral talks with the Soviet Union was - at the very least - the ultimate aim behind the launch of the CCMS. ${ }^{36}$

Given that one of the key reasons to launch the project was to reassure the allies of US commitment to the alliance, the State Department monitored their reactions closely. According to Elliot Richardson, Under Secretary of State, despite seemingly mixed reactions, the Europeans were supportive overall. ${ }^{37}$ In order to maintain momentum, the Nixon administration did not waste time and tried to obtain an early agreement in principle among the Permanent Representative for the establishment of the Committee. The assumption was that once the idea of a new Committee had been approved, the alliance could move on to the practical organisational arrangements.

The President attached personal support to the project and put it in the hands of two of his closest advisers: Daniel Patrick Moynihan, who at the time was Adviser for Urban Affairs, and Henry Kissinger, National Security Advisor. Their role was to push the project forward and to make sure that it saw the light as soon as possible and in as an unadulterated form as diplomacy would allow it. ${ }^{38}$ Kissinger liaised directly between the US NATO Delegation and the President, a further sign of its importance and urgency. Russell Train, who took over from Moynihan as head of the US CCMS 
delegation in 1971, recalls that White House stationery was routinely used for all CCMS-related documents for all internal and external communications to give everybody a sense of the President's personal interest in the matter. ${ }^{39}$ The Americans found an enthusiastic ally in Dr Gunnar Randers, Assistant Secretary General for Scientific Affairs and Acting Chairman of the CCMS, who was happy to lend his influence to the Americans and to push for quick implementation. ${ }^{40}$

The American enthusiasm was frustrated by what was perceived as the slow and cautious response of the Europeans, who pointed out that creating new structures within NATO and engaging in new fields had to be discussed thoroughly at national and alliance levels before proceeding any further. This attitude irritated the Nixon Administration, who had made proposals through NAC precisely to cut across bureaucratic lines, avoid the traditional lengthy discussion at Foreign Ministries' level and proceed without prior consultation with the member governments. Yet, they had miscalculated. Precisely because they had made their unexpected announcement in the Council, they had caused consternation and scepticism among the diplomats in Brussels as well as back in the capitals. To European ears, Nixon's plans sounded as an announcement without consultation and consideration for the allies' opinion. ${ }^{41}$

In order to smooth what could still be called a miscommunication issue, NATO Secretary General Manlio Brosio agreed to carry out a tour of the capitals and to gather support for the project. In most European capitals, Brosio was welcome, although the reactions of the European allies continued to be 'responsive in principle but cautious in practice'. ${ }^{42}$ Many governments wondered why the new body should be placed within NATO and not within the United Nations and OECD, where the wider membership would allow to transcend ideological and geographical barriers and rely on a wider range of expertise. The Americans - whose primary aim was to make the alliance more appealing to their own public - argued:

Because NATO is there. It is unique. For almost two decades now it has carried on, at ever increasing levels of complexity, a massive system of technology transfer. There has been no such sustained experience in the history of the world. If technology is the issue, NATO is uniquely the forum in which to raise it . . NATO is doubly appropriate, for here is an institution which year in and year out has been able to command attention and response at the highest levels of governments. ${ }^{43}$

In addition - the Americans argued - NATO was one of the few international organisations that had a membership consisting of countries with the same sort of problems in terms of pollution, infrastructure, urbanisation and so on, and could therefore work as a small and coherent group. They responded to the claim that international organisations like the United Nations would be more suitable by saying that precisely because of the sheer number and diversity of its members it would be impossible to reach any useful conclusion. ${ }^{44}$ They stressed that improving the image of the alliance was not only an American problem, but that it was also essential for all its members to show that there was more to NATO than tanks and fire jets. If the public had to be won over, they had to be shown that the alliance and its members understood their concerns about the environment, nuclear energy and society. 
The risk of duplication was more difficult to brush off and doubts remained. Timid attempts to liaise with the OECD were to no avail and showed that NATO struggled not to step on other organisations' toes and to be perceived as a credible forum in which to discuss the wider implications of environmental issues. In the same period several other international organisations engaged with environmental concerns. At the time of the launch of the CCMS, for example, the United Nations called for a major conference on the 'Human Environment', which took place in 1972 in Stockholm. Hence many argued that other institutions, with a larger membership, and thus a better reflection of the area affected by pollution and other environmental problems, were better suited to discuss these issues. ${ }^{45}$

The CCMS supporters argued that there was in fact no risk of duplication as the CCMS would not carry out any new research but rather collate available knowledge and ensure open discussion among experts in the field and better communication between researchers and policy-makers. In addition, it was claimed that even if, to a certain extent, there happened to be some duplication, this would not be harmful as the ultimate aim of the new initiative was to create momentum for policy change. Therefore, if it did happen that, let's say, the United Nations and NATO reached a similar conclusion, then there would be more political pressure on national governments to do something about it. ${ }^{46}$ What the CCMS supporters could not explain was what would happen if two or more international organisations reached different conclusions.

The Americans argued that the CCMS demonstrated NATO's genuine concern for the environment and that it also allowed the alliance to move on to new diplomatic ground. The environment transcended ideological barriers and could allow initiating new East-West relations. Alas, as several historians have already demonstrated, this approach quickly ran into difficulties. If the Eastern Bloc was keen to participate, the West had to face new criticism from developing countries, for whom the environment was a 'rich man's problem' and the key issues were poverty and development.

In order to give a further sign that the CCMS was very important to the President, the Americans toned down their voice in other international forums, such as, for example, during the discussions within the OECD's Ad Hoc Preparatory Committee on the Environment. At the first meeting they had pushed decisively to decide structure and aims; later they appeared more cautious and even expressed doubts as to whether the OECD was the right body for future expanded environmental work. Many NATO allies read this move as a sign that the Nixon Administration wanted the focus to remain on the CCMS. $^{47}$

The way in which high-level American officials were dispatched to the other NATO capitals to gather support, together with the demand that the new body to be set up immediately and without any further consultation, was disconcerting to the European allies. In July and August 1969 there was a dramatic increase in the pace of communication and meetings with an aim to make the CCMS operative by the end of the year. This caused consternation and uneasiness in the European capital: one British Foreign Office official commented on the margins of one of these documents with the word 'Horror! ${ }^{48}$ Many countries did not have the appropriate structures and expertise for coordinating internal work on environmental problems and were in the process of setting up new ones so as to be able to fully participate in the CCMS's work, which demanded both political will and resources. ${ }^{49}$ Yet, it was difficult - if not impossible - to resist the pressure coming form Washington without creating a major 
diplomatic crisis. By November, all European members had agreed to participate, albeit with different degrees of enthusiasm.

\section{British Scepticism}

Initially, Foreign Office officials were cautious. They were aware of Nixon's personal interest in environmental matters and of the need to improve the image of the alliance among the public. They knew that they had to appear keen and that they should not be seen to undermine the presidential initiative; at the same time, they were deeply critical of NATO's new role in environmental issues. They also feared unnecessary duplications with what was already being done more effectively by other international organisations. What was required was a careful balancing act showing willingness to participate while at the same time gaining time in the hope that the project would lose steam or divert its focus.

Archival documents reveal that several other Whitehall departments were equally sceptical of Nixon's proposals. They felt they would not be able to meet the additional demands this new body would impose on their experts. Many claimed that their staff was already 'heavily committed in various international organisations which are working in similar fields of interest at present' and that would be impossible for the United Kingdom to provide the adequate high-level expertise that the Americans expected. ${ }^{50}$ This was in fact a time when the OECD, the Council of Europe and the United Nations had launched an array of wide-ranging initiatives concerning the environment, health and society in response to the public outcry at several natural and man-made disasters that had occurred in the 1960s, as well as to youth's more general disaffection. The result was the mushrooming of conferences and experts' meetings and the consequent insupportable pressure on the limited number of experts available. ${ }^{51}$ As one FCO official pointed out:

everyone is demanding high-level representation; they cannot have it. In many cases we cannot provide low-level representation and even if we could, the result might be worse than not attending at all. .. The time has come when we have really got to decide where the least harm would be done if we dropped out altogether. ${ }^{52}$

A good example was the demand for experts in the field of air pollution, which was indeed a pressing topic at the time. The major British experts worked at the Warren Spring Laboratory in Stevenage. In early 1970 they really felt the pressure of too many international commitments, as they had to send an expert in September to the Council of Europe, a team to work on the OECD air pollution modelling project and were also asked if they could contribute to the CCMS. Their answer was clear and uncompromising: 'WSL see CCMS work as an activity of relatively low priority (as we all do), and there just is not sufficient manpower to cover WSL's other more important international commitments and CCMS as well, ${ }^{53}$ The Warren Spring Laboratory was not alone in complaining and, according to a Whitehall memo, several 'UK experts have started to protest quite loudly at having to go to CCMS meetings. If we push them any harder they may make a public stink about it. ${ }^{, 54}$ 
Several Whitehall departments were also critical of specific suggestions. For example, the Home Office opposed the idea of NATO's involvement in crime and drug trafficking as a lot of work was already being carried out by the UN's Social Defence Research Institute, the Council of Europe and Interpol, and there was no need for any interference in the delicate work of these agencies. ${ }^{55}$ The Department of Education and Science, which was going to be directly involved in the project, was highly critical too. They preferred:

not to have the Committee set up. Of course, I recognise that we cannot now oppose the Committee's creation, but it would be desirable not to lose sight of our basic attitude to this proposal; I hope we would therefore be careful not to argue too strongly in support of the present proposal to the extent that other countries would forebear to voice their misgivings. ${ }^{56}$

FCO officials were equally sceptical of Nixon's suggestion of placing the new committee under the chairmanship of ASG Gunnar Randers and his Science Committee. They thought that in his position as chairman Randers may feel encouraged to 'promote expensive projects and steer them into his own Department'. However, given the support that Randers had from Nixon himself, the FCO was fully aware that it may now be 'very difficult to keep him out of the chair, ${ }^{57}$ More importantly, the FCO thought that placing the new committee within the remit of the Science Committee might shift the emphasis further towards technological problems and away from the social sciences. The British believed, in fact, that the CCMS should engage in social science rather than in technology and research. Social sciences reduced the risk of duplicating what was already being done by other organisations. In addition, they genuinely thought that social science problems were basic to the security of the alliance and of its members. The student and worker unrests were signs that wider social issues were at stake and that it was essential to tackle them so to be able to ensure support for the alliance and for its strategic concept. In addition, according to the British, this new approach would have had the advantage of involving new experts, who could devote themselves to the CCMS. ${ }^{58}$ Hence, in their preliminary response to the American proposals, FCO officials suggested 'that the role of the Science Committee should be left open until it has become clear how much emphasis NATO wants to give to technological as opposed to social fields. ${ }^{59}$

In the corridors of Whitehall there was also frustration about not having been consulted prior to the announcement, or at the very least warned. In the eyes of the British, there appeared to be a lack of appreciation on the part of the Americans for the relatively smaller means of its partners:

it seems that the most difficult problem will be to find ways of getting the Americans to recognise the need for a selective approach to the development of intergovernmental organisation activities. Their habit of making a massive assault on the problems of the moment is sustainable by the massive resources of money and manpower they can command, but the technique is not one that transplants very readily to the countries of Western Europe. ${ }^{60}$ 
During the preliminary stages of the negotiations, the British Delegation at NATO was instructed to keep a low profile and let other delegations express concern. The United Kingdom should not appear to take the lead neither in promoting nor in slowing down the project. ${ }^{61}$

In summer 1969 Secretary General Manlio Brosio and Assistant Secretary General Gunnar Randers visited London as part of their tour of the capitals to gather information about the position of each government. At the meeting, the British emphasised that NATO should refrain from taking independent action and should instead foster interest in the work carried out by other international organisations, which were seen as better equipped to devise and execute environmental programmes. Their wider membership also allowed other international organisations to avoid giving the impression that the environment label actually hid some military, or in any case Cold War-related, intentions. In addition, FCO officials suggested that NATO focus on social rather than technological problems as the former were not yet the focus of international cooperation. Most of all, the British were very critical of the creation of a separate new committee and advised that the new initiative should start by keeping a low profile, at least at the beginning, to avoid raising unrealistic expectations among the public, which could eventually backfire. ${ }^{62}$

To the FCO's surprise, Brosio seemed to agree with most of their suggestions and spoke in favour of the new committee as 'a ginger group' that would act as a catalyst and stimulate the work of other organisations already engaged in talks. ${ }^{63}$ Brosio seemed receptive to the idea that NATO should involve itself in social rather than in technical fields and agreed that the alliance had neither the expertise nor the room to carry out new research. The impression left with the FCO officials was that Brosio was keen to follow up on Nixon's proposal but there was still time to discuss things in details. ${ }^{64}$

Brosio then travelled to the United States, where he was presented with a full list of subjects for the CCMS, mostly technological in nature. To the consternation of the British officials following his meetings in Washington, Brosio observed that "while we had felt initially that the social field was the most promising, some Governments had suggested that social problems were more complicated and that involvement with them might expose NATO to criticism'. ${ }^{65}$ The Americans found unexpected support in the French, who expressed concerns about NATO's involvement in social issues, which - according to them - could lead to unpleasant interference in the internal affairs of its members and restrict national sovereignty. ${ }^{66}$

Soon after the return of Brosio to Brussels the diplomatic exchanges regarding the CCMS moved quickly and the FCO was surprised both by the level of American involvement and by the consequent speed with which the alliance moved forward. ${ }^{67}$ It seemed already too late to influence anything, and the British - along with their European counterparts - were left with no choice but to show to be willing participants. The FCO found Randers' report 'unsatisfactory in a number of ways, notably in its sketchy and incomplete treatment of the terms of reference' ${ }^{68}$

The Preparatory Committee met in September 1969 and the British Delegation was instructed to reinforce the point that the United Kingdom saw the new body as a 'ginger group' and that as such it should not engage in research. ${ }^{69}$ Given its scepticism and frustration, the FCO was reluctant to send 
high-profile names to the meeting and resisted the American request for the presence of Sir Solly Zuckerman, Chief Scientific Adviser in the Cabinet Office. ${ }^{70}$

The Preparatory Committee's papers show evidence of the predictable European resistance to the creation of a new powerful and free-standing committee as well as the concern that the CCMS would lead the alliance into new uncharted territory where there was no consensus within the Council. The Europeans demanded clear and binding terms of reference, a limited mandate, light structure, no budget and no full-time staff. This was all agreed and it was decided that the Committee would meet in two annual plenary sessions at cabinet or subcabinet levels to provide guidance and approve new pilot projects. It was also made clear that the CCMS would be powerless to force implementation and that the members, including those who had run the pilot study, were free to act according to their national interests and priorities. ${ }^{71}$

Given that several experts had already declared themselves too busy to dedicate time to the CCMS, the Foreign Office initially planned to use the staff already available within their NATO permanent delegation for all CCMS-related work. Yet, the Americans expressed their desire for highcalibre names to show that the project had the full support of the British government and to dispel the impression that this was a purely American-driven operation. The American Ambassador in London personally visited the Foreign Office to discuss the matter and similar pressure was put on the British Ambassador in Washington. ${ }^{72}$ Yet, the FCO resisted and, to the disappointments of the Americans, eventually agreed to send Dr Cottrell, Deputy Chief Adviser. This was more than the FCO had planned to but less than the Americans had asked for, which led to frustration on both sides.

Given the British outstanding commitment to the Stockholm Conference on the Human Environment and the increasing discussions within NATO about the challenges of modern society, the FCO created a new desk within its Science and Technology Department to deal with the problems connected to the human environment, which indirectly allowed the Foreign Office to show at least a certain degree of engagement with the CCMS.

It is worth mentioning that this was also the time in which Britain was experiencing environmental disasters first hand. In the spring of 1967 the Torrey Canyon oil spill on the southwest coast of the United Kingdom affected hundreds of miles of coastline in the United Kingdom, France, Guernsey and Spain. In the summer of 1969, precisely when the FCO was pondering the British position regarding the CCMS, an estimated 50-100,000 seabirds were found dead in the Irish Sea due to sea pollution. ${ }^{74}$ These events of course made the environmental issue very pressing but this did not mean that the CCMS was seen as the best answer.

The first plenary meeting of the CCMS took place in December 1969, only eight months after Nixon's speech. ${ }^{75}$ The event was at the centre of a highly orchestrated media campaign with journalists from all NATO countries being accredited and admitted to the plenary session for the first time in December $1969 .^{76}$ In the following months, observers from non-NATO members were also admitted to plenary sessions and to the meetings of the Committee's pilot study groups, although the Council reserved the right to consider-case-by-case each time. ${ }^{77}$

Denis Richards of the British Delegation recalled the inaugural CCMS meeting as a being pervaded by 'self-congratulatory euphoria'. In his words, it was in fact: 
a rather messy meeting because, under pressure from the Americans, a topsy-turvy format was followed whereby we had first the presentation of the individual pilot projects and then, only this morning, we discussed the Committee's procedure.

According to Richards, the Americans dominated the scene by 'sheer weight of numbers', with three senior figures at the table and twenty-five others sitting behind them. The UnitedKingdom, by contrast, sported Dr Cottrell and Mr Richards at the table and nobody behind them. The Germans also sent a high-profile delegation led by Professor Dahrendorf, Parliamentary Secretary for Foreign Affairs. Concerning the presentation of potential pilot project, Richards lamented that Cottrell could not go into any detail about the British proposal on individual and group motivation due to the lack of participation of the Social Science Research Council and noted that: 'it must have been obvious to all that we had not done our homework'. ${ }^{78} \mathrm{Dr}$ Cottrell himself described his own contribution as 'a voluminous if insubstantial soufflé' and doubted whether he succeeded in hiding the proposal's lack of intellectual content. Hedid not think that:

The United Kingdom made much of an impression at the meeting. We are almost alone amongst the major countries in not sending special experts to the meeting. ... We were also nearly unique in not tabling any papers at the meeting ... I think that our failure so far to follow through at the substantive level may lead to some scepticism about our professed interest in this NATO initiative. This is not a good way to win friends and influence people. $^{79}$

The United Kingdom was also almost alone in not offering to co-pilot a project, and Alan Cottrell stressed that it was important "to consider at least whether we ought to declare fairly quickly that we would be willing to co-pilot the German study on knowledge and decision-making. If we do not join in a bit more, we shall find ourselves rather isolated ${ }^{80}$ In a private conversation with Solly Zuckerman, Cottrell warned that:

because of this very strong American interest in fostering all international aspects of environmental questions, and because they feel the need for a dependable partner, in their initiatives in this field, we have much to gain politically by responding more positively to their invitations, quite apart from technical and in some cases commercial benefits that may derive from our participation in these new international developments. ${ }^{81}$

The reason Dr Cottrell's proposal was so vague was because the FCO persisted in their effort to shift the focus to social science with a proposal for a pilot study on individual and group motivation. Unfortunately, however, they were eventually unable to pull it off because their key partner, the Social Science Research Council, refused to participate. The SSRC was afraid it might damage its own reputation and international collaborations by association with a political organisation. In addition, the 
SSRC resented that no funds were to be made available for the research to be carried out for the pilot study and that the Council was asked to pay 'for an enterprise which is essentially a diplomatic one' ${ }^{82}$

Thus, the FCO was forced to come up with an alternative plan quickly and eventually suggested a slightly amended proposal on motivation and work satisfaction. The delay and the half-baked proposal meant that once again Britain gave the impression of being recalcitrant, to great annoyance of the Americans. British officials in the NATO Delegation doubted that 'the public image of the alliance will be significantly improved as a result in the near future. ${ }^{83}$

Eventually, continuous pressure from Washington, combined with the advice coming from Cottrell and the British Delegation at NATO, persuaded the Foreign Office to step up its game and to send Sir Solly Zuckerman to the CCMS plenary meeting in October $1970 .{ }^{84}$ Yet, it was made clear that Sir Solly would be able to attend only the first day and that there was no guarantee that he or anybody of a similar rank would be sent in the future. In addition, the British representatives to the CCMS would be given a well-informed proposal for a pilot study on individual and group motivation, 'otherwise we should either look silly or else lay ourselves open to the charge that we were not serious in our declared intention of playing a constructive part in the Committee' ${ }^{85}$

It should be pointed out that although the proposal for a pilot study on individual and group motivation eventually went ahead and gained CCMS approval, the Americans were less than enthusiastic about it and regarded it as essentially a lot of hot air. Mr Moynihan thought it 'to be too narrowly conceived . . and not of sufficiently wide application in the international field ${ }^{86}$ When $\mathrm{Mr}$ Moynihan visited in London in April 1970 on his way to Brussels, he made no secret of the fact that he felt that the British remained disappointingly lukewarm about the CCMS. ${ }^{87}$ Yet, for diplomatic reasons, and to show to the other members that the British were on board, at the CCMS meeting Mr Moynihan supported the pilot study on individual and group motivation. Yet, despite the fact that the British proposal received the go-ahead, Cottrell had the distinct feeling that there was the lingering impression that 'the United Kingdom was not taking an adequate part in the work that has been put in hand' and that Britain was still thought of being recalcitrant. ${ }^{88}$

The launch of the pilot studies had happened so quickly that it became impossible - and indeed detrimental to national interests - not to participate. In the words of Ronald Arculus, of the FCO Science and Technology Department:

we are all agreed that NATO is not the best place to handle the substance of international environmental work. But the fact is that the Americans have now succeeded in starting a good deal of international discussion in the CCMS, some of which may lead to developments which may affect the UK, whether we like it or not. The Americans clearly suspect us of dragging our feet; and the other European countries . . . have since showed themselves more willing than ourselves to contribute effectively to CCMS's work. In other words, we now face a situation where we will probably need to participate in CCMS activities to protect our own interests (for example over motor vehicle safety) and to help steer them in a sensible direction. ${ }^{89}$ 
The pilot study on road safety led by the Americans was a good example indeed. According to the Director of the Road Research Laboratory, the United Kingdom could not participate in the pilot study because its experts were already heavily committed elsewhere. Yet, the study had direct implications on the car-manufacturing sector, and the British were keen to protect their carmakers. So, albeit reluctantly, they had to take part. The United Kingdom appointed Dr Lyons (Director, Road Research Laboratory, Bracknell) to lead the British experts. The Americans organised a conference on road safety in Detroit and invited representatives from the automobile industries from several NATO countries and beyond. Japan, for example, sent representatives from government and industry; Sweden was also invited and Saab and Volvo participated. Among the British car manufacturers, Rolls Royce, Kangol (seat belts) and Smiths Instruments were represented. ${ }^{90}$

Other pilot studies raised more difficult questions and directly contradicted the principle of noninterference and non-duplication established at the launch of the CCMS. It was proposed, for example, to run a pilot study on oil spills. The Foreign Office and several other departments in Whitehall were sceptical of - if not outright opposed to - the idea. There was an obvious risk of duplicating what was already being done effectively by the Inter-Governmental Maritime Consultative Organization (IMCO), which also had the non-negligible advantage of including important key nations like the Soviet Union and Japan. In the eyes of the FCO, a study on oil spills could be easily misconstrued by non-NATO members as a façade behind which hid military and strategic planning. ${ }^{91}$

In the first couple of years, the CCMS moved at a hectic pace and launched numerous pilot studies on a variety of topics. This led to the frustration of many European members, particularly the smaller ones who often did not have the sufficient number of experts and the right know-how. Even the British, who could rely on a much wider pool of experts than, let's say, Belgium, found it difficult to cope. Mr Lyons, Director of the Road Research Laboratory, put forward a rather critical view:

the American steamroller tactics in the CCMS were particularly difficult for us. It was evident that the United States was unilaterally trying to impose its own solutions upon its NATO partners. The road safety project had now snowballed. There were some 8 or 9 studies on the agenda and the US wanted the other CCMS members to play their full part in all of them. What was particularly galling was that, in most of these sectors, the United States was well behind Europe. ${ }^{92}$

In December 1970 the British Delegation to NATO sent a report about the first year of life of the CCMS, which makes interesting reading for both the frank tone and the colourful details. The CCMS was at the stage of making the first recommendations to the Council. The first eight pilot projects had developed at dramatically different speeds and many had been hampered by continued discussion about the risk of avoiding duplication and by the excessive demand on experts' time. According to the report 'the battle against duplication was not won when the terms of reference were agreed. It has to be fought over and over again'. Many Europeans resented the American high-pressure tactics: 'the authorities in Washington may take months to decide that they want the CCMS to do something; but once they have decided, they want action within days'. Sometimes meetings were called only three days ahead of time 
and, needless to say, the Americans demanded - almost without exception - high-level representation, regardless of the level of expertise.

It is no longer possible to joke about this, for fear of being taken seriously. Ask someone in the cafeteria whether he has heard that the Americans have just announced a Cabinet-level Colloquium on the Noise of Motor Bicycles to be held in Newfoundland starting tomorrow night; and he is more likely to start to his feet in apprehension than to smile back in disbelief. ${ }^{93}$

It also looked as if in its first year the CCMS had taken up an undue amount of the Council's time, for the most part on procedural questions. On the positive side, according to the British Delegation, there had not been any case of obvious duplication and 'the CCMS has certainly had a gingering-up effect on some NATO countries', particularly on those who did not have a governmental interest in the environment. In addition, smaller countries with fewer or no experts in some of these fields profited considerably from the exchange of expertise. Overall, the CCMS seemed to be building a reputation 'for injecting more urgency to international work on the environment'.

Yet, the authors pointed out that 'this Delegation has found itself acting at various times as a post office, a shock absorber and an oil can; we are regularly interposed between American dynamism and the understandable reluctance of Whitehall to provide experts at short notice for CCMS-sponsored meetings'. Finally, the UK Delegation was pleased to announce that Mr Moynihan was about to return to academic life. This was a great relief for the British officials in Brussels and London, who had found him personally difficult to deal with. The delegation suggested that 'it is possible that American interest in the CCMS may tail off after his departure'. The report concluded that the CCMS may 'go on producing some useful results, perhaps at the cost of disproportionate effort' but 'we doubt that the public image of the alliance will be significantly improved as a result in the near future'. ${ }^{94}$

The British were not alone in thinking in these terms and the most incensed were the CCMS's supporters, who were disappointed and frustrated. In an internal memo to Brosio, Randers complained that the flow of information on the status of pilot studies was slow, that progress of several studies was 'sluggish', that 'recommendations tended to be imprecise and generalised' and that there was still too much emphasis on research rather than on recommendations. Finally, despite all the efforts to avoid it, Randers also had to recognise that there were 'overlaps with efforts of other organisations.' 95

\section{The CCMS in Action}

Although the primary purpose of this article is to examine the diplomatic tensions behind the launch of the CCMS, it may be helpful to examine here briefly the subsequent development of the Committee as it offers further evidence of how the CCMS's work expanded the alliance's vision and interest in out-ofarea events.

At its first plenary session in December 1969, the CCMS launched seven pilot studies, three of which saw the United States as the pilot nation. This again showed the level of US commitment. Soon after that, Moynihan was called back to Washington and was replaced as chairman of the US delegation 
to the CCMS by Russell E. Train, Chairman of the Council on Environmental Quality. ${ }^{96}$ CCMS's responsibility remained in the White House and Train was to report directly to the President, while $\mathrm{Mr}$ Moynihan continued association to the CCMS as a consultant. ${ }^{97}$ Before leaving his CCMS post, a confidant of Patrick Moynihan informed the President that 'the CCMS is probably now the most active and productive international activity of its kind'. Yet Moynihan was aware that 'it will take a long time for the program to become self-sustaining' and warned that 'any relaxation of American effort during that interval is likely to be fatal'. ${ }^{98}$

The West Germans enthusiastically supported the Americans. The CCMS received strong personal backing from Chancellor Willy Brandt, who sent high-calibre names to all meetings. ${ }^{99}$ In the words of a British official: 'the Germans are evidently now regarded as the blue-eyed boys of the environment by the Americans'. ${ }^{100}$ This was a time in which the Federal Republic of Germany (FRG) had set on a new course in its relations with the Eastern Bloc. Ostpolitik sent alarms bells ringing in the Western capitals and many feared that new Chancellor could jeopardise West Germany's alliance to the West in the name of new German relations. The support of Willy Brant for the CCMS should therefore be seen as an attempt to reaffirm the FRG's commitment to the alliance. More specifically, the CCMS allowed Brandt to throw his support towards NATO's political and environmental dimensions rather than its purely military role, thus avoiding new tensions with the East.

The French also showed a genuine interest in the project. The CCMS - and NATO science more broadly - allowed France to take an active part in the alliance despite being out of the integrated command structure. France became increasingly more interested in the alliance's third dimension and since 1980 all Assistant Secretary Generals for Scientific Affairs have been French officials. ${ }^{101}$ However, it should not be forgotten that the other European members merely paid lip service to the programme, with some occasionally voicing their concern openly. The Norwegians, for example, were initially rather hostile towards the project. Under Prime Minister Per Borten, Norway did not participate in the CCMS. Only a few years later, following the establishment of a new Ministry of the Environment, Norway joined the Committee and took part in some pilot studies.

In 1971 NATO launched the CCMS Fellowship Programme and the CCMS continued to launch new pilot studies, which focused primarily on technology and scientific knowledge transfer. ${ }^{102}$ However, as Macekura has pointed out, in his second term Richard Nixon shifted his attention away from environmental issues and focused more on diplomatic dialogue with the East and the need to secure domestic support for it. The newly elected US President, Jimmy Carter, was equally supportive of CCMS and publicly praised its work. ${ }^{103} 1977$ was also the year of the Ekofisk oilrig blow-out, when an estimated 126,000 barrels of oil were spilled in the North Sea. Studies published in the same period showed how increasing air pollution was accelerating the degrading of Europe's most important monuments and cultural heritage sites, with Venice a case in point. The Ekofisk disaster and Venice's degrading monuments provided NATIS with further evidence of the necessity of the work of the CCMS and were amply used in its information material. ${ }^{104}$

In its early years, the CCMS played an important part in the development of treaty law. ${ }^{105}$ Taking advantage of the scientific, technical and organisational expertise found within the alliance, the CCMS became an international forum for the exchange of research ideas and new technologies on a wide-range 
of environmental matters. The list of topics addressed by the Committee over the years was wideranging and included air pollution, water pollution, spill response, hazardous waste clean-up, disaster preparedness, noise abatement, indoor air pollution, risk assessment, pollution prevention, pollution from radioactive waste stored on land and sea and the storage and dumping of chemical weapons. The CCMS also contributed studies to the protection the preservation of historic monuments and buildings.

Yet, other - possibly more appropriate - forums were launched to address the legal aspects of wide-ranging environmental problems. The 1972 Stockholm Conference on the Human Environment, in particular, gave birth to the United Nations Environment Programme (UNEP), which became responsible for coordinating most of the international community's efforts to address global environmental issues. ${ }^{106}$ After that, although the CCMS continued to serve as a forum for discussion and exchange of ideas, it was side-lined by the new body which encompassed a larger number of countries.

In second half of the 1970s there were suggestions - primarily from the United States and Italy, and occasionally the United Kingdom - that the CCMS should address the social and institutional challenges facing modern society entering the post-industrial era, which would have allowed the CCMS to find its own niche. Yet, hardly anything came of it. The sudden increase in East-West tensions following the invasion of Afghanistan brought the alliance's attention back to military defence. The CCMS and the environmental problem were quickly shifted to the back burner. On the occasion of the CCMS's tenth anniversary, experts pointed out that 'the CCMS had some early, highly visible successes and has produced some solid work over the years, but it has begun to suffer from lack of high level political attention and support' ${ }^{107}$ The CCMS continued its work until the end of the Cold War and beyond on a variety of projects as varied as forest fires, preservation of historical stained glass, aircraft noise and indoor air quality, as well as more obvious ones like environmental problems emanating from defence-related installations and activities. ${ }^{108}$

It may be worth mentioning that in the post-Cold war years, the CCMS's activities were expanded to include new partner countries. From 1997 it officially included the members of the new Euro-Atlantic Partnership Council (EAPC) and of the Mediterranean Dialogue initiative (Algeria, Egypt, Israel, Jordan, Mauritania, Morocco and Tunisia). The CCMS took into account the new strategic and security challenges with studies on the re-use of former military sites, on environmental education in the armed forces and on security related to the construction of new pipelines in the Black Sea and Caspian regions.

In 2006 the CCMS merged with the Science Committee into the new Science for Peace and Security Programme, which currently includes collaboration with partner countries in Eastern Europe as well as Russia. ${ }^{109}$

\section{Conclusion}

If we look at the history of the CCMS as the history of NATO's attempt to engage with the public and to widen its own security scope, it is clear that the new initiative - at least to a certain extent - did help develop a new scientific dimension to the alliance and contributed to the international debate on the environment. The CCMS's work proved particularly useful in the early phases of new problem areas, 
when issues were still vague and ill-defined. In 1971, for example, the conference of mayors held in Indianapolis was useful to clarify the key terms of research on the problems connected with urbanisation and to define common ground of interest. The pilot study on air-pollution produced agreement on the scientific basis and systems methodology for national air quality management programmes. The road safety pilot study contributed to the debate that eventually led to the introduction of national regulations on seat belts, inspections, auxiliary vehicle lights and alcohol tests. ${ }^{110}$

The most obvious positive result was the intensification of the exchange of scientific and technical knowledge among experts, which helped strengthen the international network of skilled professionals and to develop new methods of collaboration. The CCMS workshops and conferences helped experts establish contacts and exchange ideas with minimal bureaucratic interference from either the alliance or national governments. According to some of the experts who took part in the CCMS initiatives, the great advantage was the discussion of problems and failures, which were often neglected in official academic conferences but were 'extremely important to avoid waste of resources and time.'111

Equally important is to point out that to a certain extent the CCMS did have the 'gingering up' effect that the British had hoped. At the time of its launch, many NATO countries had neither the infrastructure nor the expertise to contribute significantly to the work of the Committee. In order to respond to American pressure, national governments sat up new agencies and diverted funds towards research and training in this field. Smaller countries with fewer or no experts in some of these fields profited considerably from exchange of expertise.

On the other hand, however, many of the CCMS recommendations remained on paper due to the lack of enthusiasm of several national governments and the costs involved. Local action was often delayed or reticent as national governments and regional authorities resented interference and often claimed that the peculiarities of their own specific situation made the CCMS's recommendations irrelevant. The CCMS's programme was indeed flexible and free from excessive bureaucratic control. The disadvantage was that it was also eclectic and fragmented, with no overarching purpose and no clearly defined raison d'être. As a result several pilot-studies 'ended in a whimper, blessed by platitudes and quietly filed away'. ${ }^{112}$ Perhaps the most important pilot study in terms of building the preliminary basis for the concept of out-of-area and crisis management operations is the pilot study on Disaster Assistance carried out by the United States and Italy, which looked at the possibility of cooperation in the case of natural and man-made disasters and which contemplated the possibility of intervening in support of countries in need outside the NATO area itself.

It is questionable, however, whether all these efforts translated into increased support for the alliance and how much the CCMS helped persuade the younger generations that NATO meant more than military defence. A cursory survey of the newspapers at the time suggests that it was the United Nations and the Stockholm Conference that led the environmental effort in the public's mind. National newspapers hardly mentioned the CCMS, and it is difficult to see how the Committee could reach its target audience. In the end it remained what many thought it would be: a group of experts talking to experts. According to NATO's Director of Information, the CCMS did not bring the alliance any closer to the public. The initial reactions were 'not enthusiastic' and ranged 'from prudent scepticism to 
outright hostility'. The younger generations, who were the primary target of the project, saw right through it and identified the CCMS as an attempt 'to solicit public favour for an unpopular military alliance'. ${ }^{113}$

Perhaps the most interesting aspect of the CCMS's history is the tense diplomatic exchange that took place behind the scenes between 1969 and 1970. Within NATO any decision is a careful balancing act that must take into consideration a variety of national interests, priorities and concerns. The Permanent Representatives and their national governments keep their eyes on their countries and on their public and, while the reputation and the success of the alliance is officially their ultimate goal, their enthusiasm is often tampered by national elections, crises and problems. The state of bilateral relations had a similarly deep effect on the behaviour of the member states. During the Cold War relations with Washington were key components of the foreign policy of all NATO members, and national governments had to find the right balance between national goals and the health of their relations with the Americans. The CCMS was a case in point. At the time, no European country wanted to disappoint Nixon, but the American modus operandi and the timing imposed on them was frustrating and difficult to handle. The result was a slow and often recalcitrant response, which frustrated diplomats and policy-makers on both sides of the Atlantic. Like so often happened in the history of NATO, it resulted in a compromise and as such it disappointed. Because it frustrated the Americans and seemed too ambitious to many Europeans, support for the CCMS faded away quickly.

More specifically, this article also demonstrates the tense state of Anglo-American relations at the time and the frustration in the corridors of Whitehall. While American leadership within the alliance was never contested, the priorities and diplomatic 'steam-roller' approach caused consternation and resentment. The very fact that the FCO had not been consulted prior to Nixon's announcement and that Britain was expected to gather European support for the American project regardless of their own concerns can be seen as a sign of Washington's recalibration of its own priorities and of its support for the European partners. In the era of détente, West Germany was becoming a privileged interlocutor and Britain's prominent role as the first point of call in Europe was under threat.

The history of NATO has often been interpreted either as an extension of American foreign policy, whereby the allies more or less simply bowed to the American will in their attempt to keep the United States tied to Europe's defence, or as an organisation with a will of its own, whereby 'NATO decided' to do something or the other. Yet, neither narrative is exact. In the words of a diplomat in the know, NATO was - and is - an 'organised controversy'. ${ }^{114}$ 
${ }^{1}$ For an effective summary of the changes in transatlantic relations in the 1970 s, see Andrea Wenger and Daniel Möckli, 'Power shifts and new security needs: NATO, European identity and the reorganisation of the West, 1967-1975', in Jussi Hanhimäki, Georges-Henri Soutou, Basil Germond, eds., The Routledge Handbook of Transatlantic Security (London: Routledge, 2010), 103-22. See also Andreas Wenger, Christian Nuenlist and Anna Locher, eds., Transforming NATO in the Cold War: Challenges beyond Deterrence in the 1960s (London: Routledge, 2006). See also André Vincent, 'The Technological Gaps: A Three-Dimensional Problem', NATO Letter, 15/10 (October 1967).

${ }^{2}$ In his analysis of the history of the protest movements, Gerhard Wettig stresses the importance of Soviet intentions and geopolitical aims. Gerhard Wettig, 'The last Soviet offensive in the Cold War: emergence and development of the campaign against NATO euromissiles, 1979-1983', Cold War History, 9/1 (2009), 79-110; Gerhard Wettig, 'Die Sowjetunion in der Auseinandersetzung über den Nato-Doppelbeschluss 1979-1983', Vierteljahrshefte fur Zeitgeschichte 57/2 (2009), 217-59; Gerhard Wettig, 'Der Kreml und die Friedensbewegung Anfang der achtziger Jahre', Vierteljahrshefte für Zeitgeschichte 60/1 (2012), 143-9. This view has been challenged by Holger Nehring and Benjamin Ziemann. See Holger Nehring and Benjamin Ziemann, 'Do all paths lead to Moscow? The NATO Dualtrack Decision and the Peace Movement - A Critique', Cold War History 12/1 (February 2012), 1-24. See also Lawrence S. Wittner, Towards Nuclear Abolition: A History of the World Nuclear Disarmament Movement, 1971 to the Present (Stanford, CA: Stanford UP, 2003); Holger Nehring, Politics of Security: British and West German Protest Movements and the Early Cold War, 1945-1970 (Oxford: Oxford University Press, 2013). Jan-Henrik Meyer and Bruno Poncharal, 'L'Européanisation de la Politique Environnementale Dans les Années 1970', Vingtième Siècle 113/1 (2012), 117-26. In the mid-1970s the peace movement expanded to include protests against civilian use of nuclear energy. These protests of course intensified in the aftermath of the nuclear disaster at Chernobyl in April 1986 and led to the first independent peace and ecological movement in the German Democratic Republic (GDR) and in other Eastern European states. Franz-Josef Brüggemeier, Tschernobyl. 26 April 1986: Die ökologische Herausforderung (Munich: Dtv, 1998).

${ }^{3}$ Gregory Flynn, 'Public Opinion and Atlantic Defence', NATO Review 31/5 (September 1983).

${ }^{4}$ Article 2 is often refered to as the 'Canadian article' as it was sponsored by the Canadian government during the treaty negotiations. John C. Milloy, The North Atlantic Treaty Organization, 1948-1957: Community or Alliance? (Montreal: McGill Queen's University Press, 2006).

${ }^{5}$ During the Cold War, NATO science was divided into pure science, defence science and military science. Not surprisingly, military science was the first to be established (1951). It included activities under various NATO military authorities such as the Advisory Group for Aerospace Research and Development; the SACLANT Anti-Submarine Warfare Research Centre in La Spezia; and the SHAPE Technical Centre.

${ }^{6}$ NATO and Science: Facts about the Activities of the Science Committee of the North Atlantic Treaty Organisation, 1958-1967 (Paris, NATO Scientific Affairs Division, 1967), 2.

7 Final Communiqué, Points 25-29, 16-19 December $1957 . \quad$ URL: Www.nato.int/cps/en/natolive/official_texts_17551.htm (last retrieved on 1 Oct. 2015). In addition to NATO's own official publication, the most useful academic contributions to study of the history of 
NATO science are Francis A. Beer, Integration and Disintegration in NATO: Processes of Alliance Cohesion and Prospects for Atlantic Community (Columbus: Ohio State University Press, 1969); John Krige, American Hegemony and the Postwar Reconstruction of Science in Europe (Cambridge, MA: MIT Press, 2008); John Krige, 'NATO and the Strengthening of Western Science in the Post-Sputnik Era', Minerva, 38/1 (2000), 81-108; Jen Erik Fenstad, 'NATO and Science', European Review, 17/3-4 (2009), 487-97; Russell E. Train, 'A new approach to international environmental cooperation: the NATO Committee on the Challenges of Modern Society', Kansas Law Review 22/2 (Winter 1974), 167-91. I have retraced the history of the Science Committee and of the CCMS in chapter 7: 'Engaging with Science, Academia and the Leaders of Tomorrow' in Linda Risso, Propaganda and Intelligence in the Cold War: The NATO Information Service (London: Routledge, 2014). Finally, see Stephen Macekura, 'The Limits of the Global Community: The Nixon Administration and Global Environmental Politics', Cold War History, 11, 4 (2011), 489-518. The documents of the Science Committee are available in the NATO Archives, series AC/137. By 1966 the members of staff of the Science Committee numbered ten persons, two thirds of whom were concerned with pure science.

${ }^{8}$ NATO and Science: An Account of the Activities of the NATO Science Committee, 1958-1972 (Brussels, NATO Scientific Affairs Division, 1973).

${ }^{9}$ Krige, American Hegemony. Between 1959 and 1966, NATO's pure science budget rose from \$1.15 million to $\$ 4.2$ million. However, in the years between 1962 and 1966 the budget remained in the area of $\$ 4$ million. 'Science Committee. The NATO Fellowship Programme. Report on the Programme for 1964', 15 Feb. 1966, NATO Archives (henceforward NA), AC/137-D/271.

${ }^{10}$ See more details about American frustration in Beer, Integration, 217-219.

${ }^{11}$ Geeral Norstad in particular was keen to promote collaboration in science purely as a means of maintaining a convincing deterrent. Gen. Lauris Norstad, 'NATO's Military Future: A Stronger "Shield", a Sharper "Sword"' General Electric Defense Quarterly, 1/1 (Apr., 1958) as quoted in Beer, Integration, 223-4. The lack of progress pushed the Italian Foreign Minister, Amintore Fanfani, to express concern about the increasingly dangerous 'technological gap' between Europe and the United States. See Fanfani's speech at the Ministerial meeting of June 1966. His proposal was the result of an Italian Foreign Ministry study, which had been launched after his conversation with Secretary of State Dean Rusk in June 1966. At the time, the idea of a 'Marshall Plan for Technology' was first discussed, see Foreign Relations of the United States, 1964-1968, vol. XIII, Document 205, URL: http:/history.state.gov/historicaldocuments/frus1964-68v13/d205 (last retrieved on 1 Oct. 2015. Henceforward FRUS). The Council recognised the problem and appointed a Special Working Group on International Technological Co-operation (AC/262) to explore the possibility of expanding the NATO science programme with the specific aim of bringing Western Europe to the same level of investment in science as the United States. The Special Working Group worked under the chairmanship of Secretary General Manlio Brosio, who delegated day-to-day responsibility to André Vincent, a French member of the International Staff. André Vincent, 'The Technological Gap: A Three-Dimensional Problem', NATO Letter, 15/10 (Oct. 1967). Yet again, the discussions were hampered by internal disagreements about the level of spending and reluctance to share details about the most-cutting edge projects. The result was, once again, a compromise that was destined to disappoint all parties concerned. 'Resolution on 
International Technological Co-operation', URL: www.nato.int/docu/comm/49-95/c670613b.htm (last retrieved on 1 Oct. 2015).

${ }^{12}$ For a list of institutions, see NA, AC/137-WP 37, 22 May 1967.

${ }^{13}$ Krige, American Hegemony; Beer, Integration.

${ }^{14}$ The birth of the environmental movement is usually dated back to the publication of Rachel Carson's Silent Spring in 1962. For helpful introductions to environmental history, see John R. MacNeill and Corinna R. Unger, eds., Environmental Histories of the Cold War (Cambridge: Cambridge University Press, 2010); John R. Mac Neill and Alan Roe, eds., Global Environmental History: An Introductory Reader (London: Routledge, 2013).

${ }^{15}$ Garret J. Martin, General de Gaulle's Cold War: Challenging American Hegemony, 1963-1968 (New York/Oxford: Berghahn Books, 2013).

${ }^{16}$ NATO's dual approach of maintaining credible collective defence based on the principles of MC 14/3, while at the same time pursuing a policy détente through dialogue with the Soviet Union and the countries of the Warsaw Pact, was to provide the foundation for Alliance policy for the next twenty years. Frédéric Bozo, 'Détente Versus Alliance: France, the United States and the Politics of the Harmel Report', Contemporary European History, 7/3 (Nov. 1998), 343-60. Helga Haftendorn, 'The Adaptation of the NATO Alliance to a Period of Détente: The 1967 Harmel Report', in Wilfried Loth, ed., Crises and Compromises: The European Project 1963-1969, (Baden-Baden: Nomos Verlag, 2001), 285-322. Helga Haftendorn, NATO and the Nuclear Revolution: A Crisis of Credibility, 1966-1967 (Oxford: Oxford University Press, 1996).

${ }^{17}$ Address by President Nixon to the North Atlantic Council, Washington, 10 Apr. 1969, Foreign Relations, 1969-1976, Volume I, Foundations of Foreign Policy (URL: 20012009.state.gov/r/pa/ho/frus/nixon/i/20701.htm (last retrieved on 1 Oct. 2015). This suggestion was included in the Final Communiqué (Point 14), URL: www.nato.int/docu/comm/49-95/c690410a.htm (last retrieved on 1 Oct. 2015).

${ }^{18}$ Paul Von Ward, Glen R. Kendall and Jens C. Bresee, 'Ten years of CCMS. The Record and the Future - Part 1', NATO Review, $27 / 6$ (Dec. 1979).

${ }^{19}$ Macekura 'The Limits'; J. Brooks Flippen, 'Richard Nixon, Russell Train, and the Birth of Modern American Environmental Policy', Environmetal History 32 (July 2008), 1613-38; Jacob Darwin Hamblin, 'Environmentalism for the Atlantic Alliance: NATO's Experiment in the "Challenges of Modernd Society", Environmental History 15/1 (Jan. 2010), 54-75.

${ }^{20}$ Summary Record of a Meeting of the Council held on Wednesday, 15 Oct. 1969 at 10:15am, 28 Oct. 1969, NA, CR(69)46. For the consultation about the terms of reference and focus of the new committee, see 'Environmental problems. Report by the Secretary General', 8 July 1969. NA, PO/69/338; Preparatory Committee on the Challenges of Modern Society, 6 Oct. 1969. NA, CM(69)43. Von Ward P., Kendall G.R. and Bresee J.C., 'Ten years of CCMS'. Initially, the Federal Republic of Germany was sceptical and saw the initiative as an attempt by the United States to regain international terrain after the lost Vietnam War, Kai F. Hünemörder, Die Frühgeschichte der globalen Umweltkrise und die Formierung der deutschen Umweltpolitik (1950-1973), (Stuttgart: Franz Steiner Verlag, 2004).

${ }^{21}$ Risso, Propaganda, Ch. 7. 
22 'Environmental problems'. Report by the Secretary General, 8 July 1969. NA, PO/69/338. For these reasons, the launch of the CCMS was enthusiastically welcomed by the Atlantic Treaty Association and the North Atlantic Assembly as they saw it as a means to bring the alliance closer to the citizens and their daily concerns, 'Atlantic Treaty Association: Sixteenth General Assembly. Final Resolution', NATO Letter, 18/11-12 (Oct./Nov. 1970).

${ }^{23}$ The first pilot studies were road safety, disaster relief, air pollution, open water pollution, inland water pollution, transmission of scientific knowledge and problems of individual and group motivation in modern industrial society. Given its role in launching CCMS, it is not surprising that the United States volunteered to act as pilot country of three out of the seven first studies carried out by CCMS. 'CCMS recommends seven pilot studies at first meeting', NATO Letter, 18/1 (Jan. 1970).

${ }^{24}$ Preparatory Committee on the Challenges of Modern Society, 6 Oct. 1969, NA, CM(69)43; 'Committee on the Challenges of Modern Society', NATO Letter, 18/1 (Jan. 1970).

25 'Environmental problems'. Report by the Secretary General, 8 July 1969, NA, PO/69/338.

${ }^{26}$ NATO answered this point by maintaining that it was crucial to have several independent studies showing the need for urgent action and make recommendations more forceful, see Preparatory Committee on the Challenges of Modern Society, 6 Oct. 1969. NA, CM(69)43.

${ }^{27}$ Risso, Propaganda, Ch. 7.

${ }^{28}$ 'Committee on the Challenges of Modern Society and NATO's third dimension', NATO Letter, 18/2 (Feb. 1970).

${ }^{29}$ More details about this film are provided in Risso, Propaganda, 192-3. A copy of the film can be found in the media archives of the Imperial War Museum in London.

${ }^{30}$ Doc. 44. Memorandum from the President's Assistant for Urban Affairs (Moynihan) to President Nixon. Washington, 1 July 1970. FRUS, 1969-1976, vol. 41: Western Europe; NATO, 175-8.

31 'Conference of National Information Officials. Report by the Chairman', 3 June 1971, NA, $\mathrm{CM}(71) 44$.

${ }^{32}$ Nixon was genuinely committed to environmental protection. At the beginning of his presidency, he established the Council on Environmental Quality (CEQ) at the White House and the Environmental Protection Agency (EPA) to formulate and oversee implementation of national environmental policy, as well as the National Oceanic and Atmospheric Administration (NOAA) within the Department of Commerce to complement EPA's efforts. Macekura, 'The Limits'.

${ }^{33}$ Doc. 1. Intelligence Memorandum prepared in the Central Intelligence Agency. OCI No. 0549/69 Washington, 21 Jan. 1969. FRUS, 1969-1976, vol. 41: Western Europe; NATO, 1.

${ }^{34}$ Doc. 4. Telegram From the Mission to the North Atlantic Treaty Organization to the Department of State. Brussels, 23 Jan. 1969, 2225Z. FRUS, 1969-1976, vol. 41: Western Europe; NATO, 19-21.

${ }^{35}$ Macekura, 'The Limits'.

${ }^{36}$ Hamblin, 'Environmentalism'. See several documents published in FRUS, 1969-1976, vol. 41: Western Europe; NATO.

${ }^{37}$ Doc. 16. Memorandum from the Under Secretary of State (Richardson) to President Nixon. Washington, 6 May 1969. FRUS, 1969-1976, vol. 41: Western Europe; NATO, 60-2. 
${ }^{38}$ Arthur F. Burns (Chairman on the Council of Economic Advisers and future Chairman of the Federal reserve) and James E. Allen (US Commissioner of Education) were also assigned to the proejct. See Doc. 16. Memorandum From the Under Secretary of State (Richardson) to President Nixon. Washington, 6 May 1969. FRUS, 1969-1976, vol. 41: Western Europe; NATO, 60-2.

${ }^{39}$ Russell E. Train, Politics, Pollution and Pandas: An environmental memoir (Washington: Island Press, 2003), 151.

${ }^{40}$ See for example: To all national delegations from ASG for Scientific Affairs, 18 July 1969. NA, ASG.SA(69)201.

${ }^{41}$ Doc. 19. Memorandum from the President's Assistant for National Security Affairs (Kissinger) to President Nixon. Washington, 2 June 1969. FRUS, 1969-1976, vol. 41: Western Europe; NATO, 65-6.

${ }^{42}$ Note to Mr Bendall and Mr Williams from J.P. Waterfield, 23 June 1969, folio 6. National Archives, Kew, London (henceforward UKNA), CAB 168/278.

${ }^{43}$ Moynihan quoted in 'Committee on the Challenges of Modern Society,' NATO Letter, Jan. 1970, 8.

${ }^{44}$ Train, 'A New Approach'; 'Committee on the Challenges of Modern Society' NATO Letter, Jan. $1970,8$.

${ }^{45}$ For the failed attempt to laise with the OECD, see the last two pages of Progress Report by the Chairman of the Committee on the Challenges of Modern Society, 15 May 1970. NA, CM(70)19(Final); Letter to C.J. Audland from J.C.A. Roper, 26 November 1969, folio 78. UKNA, CAB 168/279.

${ }^{46}$ See, for example, Mr Gunnar Randers, ASG for Scientific Affairs and Acting Chairman of the CCMS, quoted in 'Committee on the Challenges of Modern Society' NATO Letter, Jan. 1970, 8.

${ }^{47}$ OECD: Ad Hoc Preparatory Committee on the Environment, Telegram from FCO to UKDEL NATO, telno 28, 24 Apr. 1970, folio 204. UKNA, CAB 168/281.

${ }^{48}$ Copy of Letter to Randers from US Permanent Representative, 23 July 1969, folio 14B. UKNA, CAB $168 / 278$.

${ }^{49}$ Doc. 23. Telegram from the Under Secretary of State (Richardson) to the Department of State. London, 6 Nov. 1969, 1901Z. FRUS, 1969-1976, vol. 41: Western Europe; NATO, 71-3.

${ }^{50}$ Letter to Dr Cottrell from J.N. Elam, 24 June 1969 with encl. folio 7. UKNA, CAB 168/278.

${ }^{51}$ Letter to R. Arculus from R Wakefield, Aug. 1970, folio 289. UKNA, CAB 168/283.

${ }^{52}$ Letter to R. Arculus from J.E. Beddoe, 17 Aug. 1970, folio 290. UKNA, CAB 168/283.

${ }^{53}$ Letter to R. Arculus from R. Wakefield, Aug. 1970, folio 289. UKNA, CAB 168/283.

${ }^{54}$ Brief for Sir Solly Zuckerman from Alan Smith, 2 Oct. 1970, folio 304. UKNA, CAM 168/284.

${ }^{55}$ Letter to Dr Cottrell from J.N. Elam, 24 June 1969, with encl. folio 7. UKNA, CAB 168/278.

${ }^{56}$ Letter to R.Q. Braithwaite from E.C. Appleyard, 2 Oct. 1969, folio 48. UKNA, CAB 168/279.

${ }^{57}$ Telegram to UKDEL NATO from FCO, Telno. 6 Saving, 11 July 1969, folio 13A. UKNA, CAB $168 / 278$.

${ }^{58}$ Letter to Dr Cottrell from J.D. Bletchly, 16 Feb. 1970, folio 13. UKNA, CAB 168/280.

${ }^{59}$ Telegram to UKDEL NATO from FCO, Telno. 6 Saving, 11 July 1969, folio 13A. UKNA, CAB $168 / 278$

${ }^{60}$ Letter to C.J. Audland from E.C. Appleyard, 1 Oct. 1969, folio 46. UKNA, CAB 168/279. 
${ }^{61}$ Telegram to UKDEL NATO from FCO, Telno. 6 Saving, 11 July 1969, folio 13A. UKNA, CAB $168 / 278$.

${ }^{62}$ Note to Mr Bendall and Mr Williams from J.P. Waterfield, 23 June 1969, folio 6. UKNA, CAB $168 / 278$.

${ }^{63}$ Minute to Mr Williams from J.P. Waterfield, 25 June 1969, folio 8. UKNA, CAB 168/278.

${ }^{64}$ Telegram to FCO (Dr Cottrell) from Sir Burrows, Telno. 374, 20 June 1969. Enclosed to folio 8. UKNA, CAB 168/278.

${ }^{65}$ Minute to Dr Cottrell from Alan Smith, 19 Feb. 1970, folio 119. UKNA, CAB 168/280. See also Brosio's official report to the NAC: Environmental problems. Report by the Secretary General, 8 July 1969. NA, PO/69/338.

${ }^{66}$ Telegram to UKDEL NATO from FCO, Telno. 6 Saving, 11 July 1969, folio 13A. UKNA, CAB $168 / 278$.

${ }^{67}$ The Council approved Brosio's report on 15 July. Two days later Randers informed all national delegations that the Preparatory Committee was to report back to the Council on 15 Oct. He suggested that the Committee met on 8-9 Sept. and already asked for comments on points 6-8 of Brosio's report by 10 Aug. See: To all national delegations from ASG for Scientific Affairs, 17 July 1969. NA, ASG.SA(69)201. The terms of reference and procedure of the Preparatory Committee were circulate in late August. Preparatory Committee on the Challenges of Modern Society. Note by the Chairman. 26 Aug. 1969. NA, AC/269-D/1.

${ }^{68}$ Telegram to UKDEL NATO from FCO, 29 Aug. 1969, Telno. 7 Saving, folio 26. UKNA, CAB $168 / 278$.

${ }^{69}$ Letter to E.C. Appleyard from R.Q. Braithwaite, 9 Oct. 1969, folio 52. UKNA, CAB 168/279.

${ }^{70}$ Telegram to UKDEL NATO from FCO, 4 Sept. 1969, Telno. 299, folio 27. UKNA, CAB 168/278.

${ }^{71}$ NATO archival documents relating to the work of the Preparatory Committee are gathered in AC/269 (1969). The papers of the CCMS, can be found in AC/274 (1969-2006)

${ }^{72}$ Letter to C.J. Audland from Dr Cottrell, 25 Nov. 1969, folio 77. UKNA, CAB 168/279. Minute to Sir Solly from Dr Atkinson, 19 Feb. 1970, folio 118A; and Minute to Dr Cottrell from Dr Atkinson, 24 Feb. 1970, folio 119A, both in UKNA, CAB 168/280.

${ }^{73}$ The key person was Frank Wheeler. Letter to Dr Cottrell from C.J. Audland, 19 Nov. 1969, folio 74. UKNA, CAB 168/279.

${ }^{74}$ Report of the Natural Environment Research Council, The Seabird Wreck of 1969 in the Irish Sea, edited by Dr M.W. Holdgate. See also Jon Tinker, '1969 Seabird Wreck: PCBs probably guilty', New Scientist and Science Journal, 8 Apr. 1971, 69.

${ }^{75}$ Preparatory Committee on the Challenges of Modern Society. Note by the Chairman. 6 Oct. 1969. NA, CM(69)43. Preparatory Committee on the Challenges of Modern Society. Draft report to the Council. Note by the Chairman, 15 Sept. 1969. NA, AC/269-D/2. For the proceedings of the Preparatory Committee and list of participants, see: Preparatory Committee on the Challenges of Modern Society. Summary record of a meeting held at the NATO Headquarters, Brussels, 39, on $8^{\text {th }}$ $10^{\text {th }}$ September 1969,10 Oct. 1969. NA, AC/269-R/1. 
${ }^{76}$ Progress Report by the Chairman of the Committee on the Challenges of Modern Society, 15 May 1970. NA, CM(70)19(Final).

${ }^{77}$ Decisions of the Council on the recommendations by the Committee on the Challenges of Modern Society: Document CM(70)14, 14 May 70. NA, PO/70/235 (Revise). For an example of the ad-hoc approach to the admission of observers, see Observers to the next meeting of the Committee on the Challenges of Modern Society, 1 Apr. 1971. NA, PO/71/180.

${ }^{78}$ Letter to J. Thomas from D.E. Richards, 10 Dec. 1969, folio 86. UKNA, CAB 168/279. Cottrell's address was reproduced in the NATO Letter 18/2 (Feb. 1970) along with the speeches of the other key speakers. Cottrell's intervention appears indeed much shorter, more vague and with more hints of scepticism than the others published in the same article.

${ }^{79}$ Letter to Sir Zuckerman from Dr Cottrell, 11 Dec. 1969, folio 87. UKNA, CAB 168/279.

${ }^{80}$ Letter to Sir Zuckerman from Dr Cottrell, 11 Dec. 1969, folio 87. UKNA, CAB 168/279.

${ }^{81}$ Minute to Sir Solly Zuckerman and Sir Burke Trend from Dr Cottrell on UK-US cooperation in international organisations (NATO CCMS, OECD, ECE), 21 Apr. 1970, folio 194. UKNA, CAB $168 / 281$

${ }^{82}$ Letter to E.C. Appleyard from H.C. Rackham, 15 Dec. 1969, folio 88. UKNA, CAB 168/279.

${ }^{83}$ Annex C: Environmental Problems, 7 Dec. 1970, folio 352. UKNA, CAB 168/284.

${ }^{84}$ Letter to Sir Solly Zuckerman from Sir Denis Greenhill, 9 Oct. 1970, folio 314. UKNA, CAB $168 / 284$. For a list of national delegates attending the meeting of the Committee on the Challenges of Modern Society from 19 to 20 Oct. 1970 and for a summary of the discussions and conclusions, see CCMS, Summary record of a meeting held at the NATO headquarters, on $19^{\text {th }}$ and $20^{\text {th }}$ October 1970. 11 Dec. 1970. UKNA, AC/274-R/5.

${ }^{85}$ Personal minute to Dr Cottrell from J.N. Elam, 12 Mar. 1970, Folio 139. Title: 'UK Pilot Study for the NATO Committee on the Challenges of Modern Society (CCMS)'. UKNA, CAB 168/280. The pilot study on individual and group motivation was chaired by Dr N.A.B Wilson, Navy psychologist in Department of Defence. Initially the British contribution was to be a joint effort betwen the Department of Employment and Productivity and the FCO. It was later agreed that the study would be run entirely by the DEP. Letter to R. Arculus from Alan Smith enclosing a Note of Mtg held in AHC's Room on 24.2.80, 27 Feb. 1970. Folio 122. UKNA, CAB 168/280.

${ }^{86}$ Telegram to FCO from Washington, telno. 1011, 6 Apr. 1970, folio 175. UKNA, CAB 168/281.

${ }^{87}$ Note of a meeting between the Secretary of State for Local Government and Regional Planning and Dr Moynihan, Principal Adviser to the President on Thursday, 16 Apr. 1970, 17 Apr. 1970, folio 191. UKNA, CAB 168/281.

${ }^{88}$ Telegram to FCO from UKDEL NATO, telno. 200, 15 Apr. 1970, folio 189. UKNA, CAB 168/281.

${ }^{89}$ Letter to W.R. Cox from R Arculus, 27 Apr. 1970, folio 206. UKNA, CAB 168/281.

${ }^{90}$ Letter to A.H. Cottrell from D.J. Lyons, 31 Mar. 1970, folio 157. UKNA, CAB 168/281.

${ }^{91}$ From Mr Steward to UKDEL NATO, telno. 156, 1 May 1970, folio 241. UKNA, CAB 168/282. IMCO changed its name in 1982 to today's International Maritime Organization (IMO).

92 NATO CCMS Road Safety Study: Record of Conversation in FCO on $29^{\text {th }}$ May 1970, 2 June 1970, folio 245. UKNA, CAB 168/282. 
93 Annex C: Environmental Problems, 7 Dec. 1970, folio 352. UKNA, CAB 168/284.

94 Annex C: Environmental Problems, 7 Dec. 1970, folio 352. UKNA, CAB 168/284. About the British frustrations in handling Moynihan, an internal FCO document mentions that: 'He is conscious of his Cabinet rank and he is a man of forceful temperament. He has tended to exaggerate what NATO can usefully do in the environmental field'. Letter to C. Gilbraith from T.L.A. Daunt, 28 Sept. 1970, folio 301. UKNA, CAB, 168/284.

${ }^{95}$ Methods of work of the CCMS. From ASG for Scientific Affairs to Secretary General [no date]. NA, ASG(71)094. The CCM working methods were subsequently reviewed to streamline the flow of information, which included the appointment of liaison officers, see Methods of work of the CCMS. From Secretaty General to Permanent Representatives, 19 May 1971. NA, PO/71/240; and CCMS procedures: Conclusions of PO/71/240 as discussed by Delegations on 18 June 1971. 22 June 1971. NA, PO/71/295.

${ }^{96}$ Train later became Administrator of the Environmental Protection Agency (from Sept. 1973 to Jan. 1977). He was Founder Chairman Emeritus of World Wildlife Fund (WWF).

${ }^{97}$ Letter to Sir Solly Zuckerman from Stephen H. Rogers, 13 Jan. 1971, folio 359. UKNA, CAB $168 / 285$. It includes a copy of the press release.

${ }^{98}$ Doc. 44. Memorandum From the President's Assistant for Urban Affairs (Moynihan) to President Nixon. Washington, July 1, 1970. FRUS, 1969-1976, vol. 41: Western Europe; NATO, 175-8.

${ }^{99}$ Doc. 44. Memorandum From the President's Assistant for Urban Affairs (Moynihan) to President Nixon. Washington, July 1, 1970. FRUS, 1969-1976, vol. 41: Western Europe; NATO, 175-8.

${ }^{100}$ Telegram to FCO from UKDEL NATO, Telno 11 Saving, 11 Nov. 1971, folio 463A. UKNA, CAB $168 / 288$.

${ }^{101}$ Principal officials at the NATO International Staff, URL: www.nato.int/cv/is/home2.htm\#ASG-SA (last consulted on 1 Feb. 2015).

${ }^{102}$ CCMS: Fellowship programme for public policy and technology related to the environment. Note by the Chairman. 9 Apr. 1971. NA, AC/274-N/20. The scheme was partially financed by the NATO Civil Budget and by private and national sponsorships.

${ }^{103}$ Sampas J.G., 'New US Administration Reaffirms Strong Support for CCMS During Plenary Session', NATO Review 25/6 (Dec. 1977).

104 The NATO Review dedicated its cover page and several articles to pollution in Venice. Issue 27/6 (Dec. 1979).

${ }^{105}$ To cite one example, a CCMS technical study on oil spills initiated in 1969 led to a NATO resolution calling for an international effort to prevent further degradation of the world's oceans, which fed into the International Convention for the Prevention of Pollution from Ships (MARPOL).

${ }^{106}$ Other organisations such as the Organisation for Economic Co-operation and Development (OECD), the World Health Organisation (WHO) and the International Maritime Organisation (IMO) also became important actors in the field and eclipsed the role of the CCMS.

${ }^{107}$ Von Ward, 'Ten years of CCMS - Part 1', 13.

${ }^{108}$ For a full list of the projects carried out after 1987, see Science for Peace and Security Programme: List of reports of nationally-funded activities (NFA) published under the former committee on 
challenges of modern society (CCMS). Avialable at http://www.nato.int/science/2012/LISPUBNFA.pdf (last retriecved on 1 Oct. 2015). More titles can be found on the website of the US Environmental Protection Agency.

${ }^{109}$ For more information, see the SPS website at URL: www.nato.int/cps/en/natolive/78209.htm (last retrieved on 1 Feb. 2015).

${ }^{110}$ Von Ward, 'Ten Years of CCMS - Part 1', 16-7.

${ }^{111}$ Paul Von Ward, Glen R. Kendall and Jens C. Bresee, 'Ten Years of CCMS: the Record and the Future - Part 2', NATO Review 28/1 (Feb. 1980), 18.

${ }^{112}$ Von Ward, 'Ten Years of CCMS - Part 2', 18.

${ }^{113}$ Memorandum from Director of Information to the Committee on Information and Cultural Relations, 24 Feb. 1971. NA, MEMO(71)3, 24 Feb. 1971.

${ }^{114}$ In the words of Harlan Cleveland, US Permanent Representative to NATO. See: Doc. 4. Telegram From the Mission to the North Atlantic Treaty Organization to the Department of State. Brussels, 23 Jan. 1969, 2225Z. FRUS, 1969-1976, vol. 41: Western Europe; NATO, 19-21. 